\title{
Nuclear Research Pioneer Pavle Savić a Scientist in Pursuit of Truth
}

\author{
Jelena Samardžić ${ }^{1)}$
}

\begin{abstract}
This publishing year of the Scientific Technical Review is dedicated to Pavle Savić, an internationally recognized scientist who made a great contribution to discovery of nuclear fission, participated in the experiments related to the low temperature physic phenomena and published a series of works on cosmogony. He was a close associate of the Nobel laureates Irène Joliot Curie and Frédéric Joliot and Pyotr Leonidovich Kapitsa. His scientific work and his social engagement were driven by a struggle for truth, which he considered the basic moral imperative of a scientist. During the Second World War he was fighting for liberation from the Nazis as a member of the Yugoslavian partisans, and when the war was over he took a significant role in creating and development of science and education of a new country. He fought for the peaceful use of new scientific and technological accomplishments and took part in education of the generations of young scientists fighting constantly for their position in society.
\end{abstract}

Key words: Pavle Savić, nuclear physics, scientist, research, education and social engagement.

T has been 110 years since the birth of Pavle Savić, one of 1 the greatest scientists of our nation, outstanding researcher, revolutionary, participant in the creation of new state, professor, academician and a candidate for the Nobel Prize. He was born in Thessaloniki, Greece, on January $10^{\text {th }}, 1909$. His father, Petar $(1878-1951)$, received a state scholarship to study medicine in France, but was assigned by the state authorities to study veterinary medicine instead. As a veterinarian, he was assigned to his first service in Aleksinac, where he married Ana Stojanović (1885 - 1895), sister of Kosta Stojanović (18671921), professor of the Grand School, translator of Atomistic by Ruđer Bošković and the Minister of Economy and Finance of the Kingdom of Serbia. From Aleksinac Petar was deployed to serve in the free customs zone of Serbia in Thessaloniki, where Pavle, the oldest of five children, was born. Pavle had two brothers and two sisters, Slobodan and Ljubiša and Slobodanka and Vera $[1,6]$.

Because of the nature of his father's job, their family was living in different places. During the Balkan wars and the First World War they stayed in Svilajnac, where Pavle started his primary education. After the First World War, they moved to Belgrade where he finished primary school and enrolled the Second Belgrade Gymnasium. He finished the first four grades and the junior prom in Belgrade in 1923. His gymnasium education was completed in Požarevac, where he graduated in 1927. During his school days he was primarily interested in natural sciences, mathematics, physics and chemistry and, driven by curiosity and imagination, he expanded his interests and work outside the school curriculum. At the same time he was practicing scouting and radio amateurism, writing essays and participating in the pupil's literary societies "Mladost" in Belgrade and "Razvitak" in Požarevac, and he was an associate in the Belgrade pupil magazine "Pokušaj" $[1,2]$.

\footnotetext{
1) Interklima d.o.o., Kneza Miloša 161, 36210 Vrnjačka Banja, SERBIA Correspondence to: Samardžić J., e-mail: jelenadjsamardzic@gmail.com
}

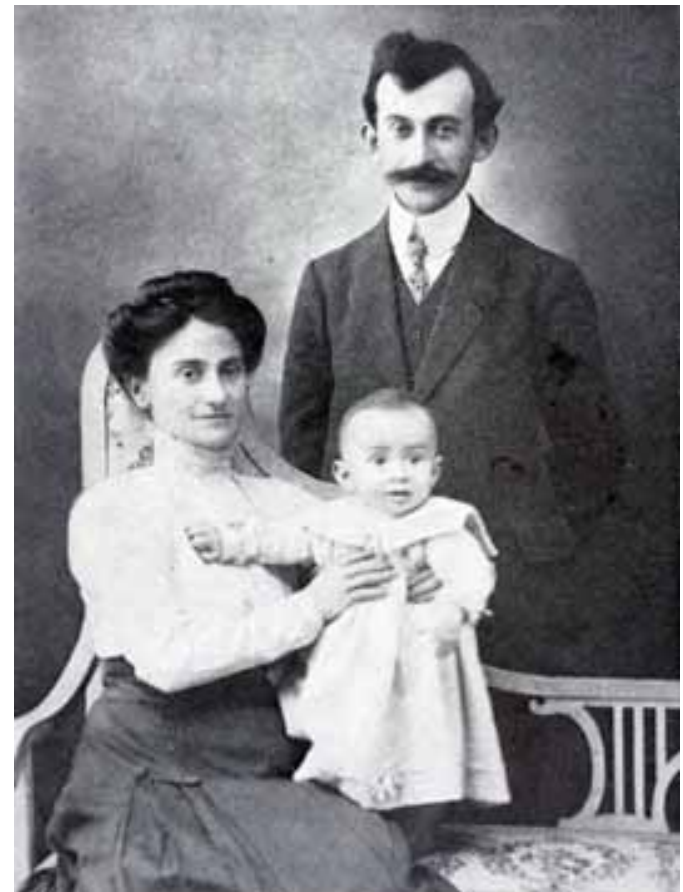

Figure 1. Mother Ana, father Petar - Pera and Pavle Savić in Thessaloniki, 1909 [2]

After graduating from the gymnasium, Pavle Savić enrolled the Department of Physics of the Faculty of Philosophy in Belgrade to study physical chemistry. Thanks to the quality of his work and the small number of students of the physical chemistry, in the second year he became a volunteer assistant with Professor Miloje Stojiljković, head of the Department and the Manager of the Institute for Physical Chemistry. 
According to the conditions and possibilities existing at that time at the Belgrade University, Savić was studying diligently, working in the laboratory and following papers in French and German.

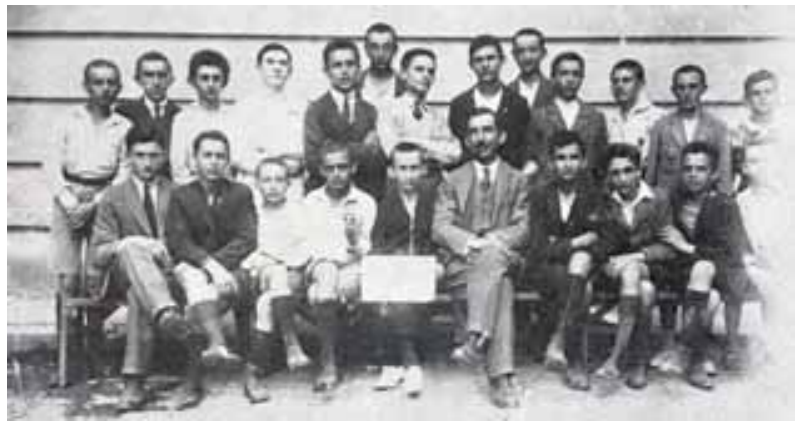

Figure 2. Administration of the Student Literary Society "Mladost" in the Second Boys Gymnasium, 1923. Pavle Savić is sitting in the first row, with the copy of the issue of the "Pokušaj" magazine in his hands [2]

He graduated in June and received a diploma in October 1932. During 1932 and 1933 he finished his service in the Royal Yugoslav Army in Sarajevo. Upon arriving from the army, he was working as an assistant at the Department of Physics at the Faculty of Philosophy, but because of personal disagreement with professor Stojiljković, he resigned his position and started to work as an assistant with Professor of Physics at the Medical Faculty in Belgrade, Dragoljub Jovanović, a former associate of Maria Curie at the Radium Institute in Paris. In 1934, up on the recommendation of Professor Jovanović, Savić was appointed for permanent assistant at the Radiology Institute of the Medical Faculty in Belgrade. He already published practicum handbook of physics for medical students and with Professor Jovanović his first scientific paper in the journal of the French Academy of Sciences.

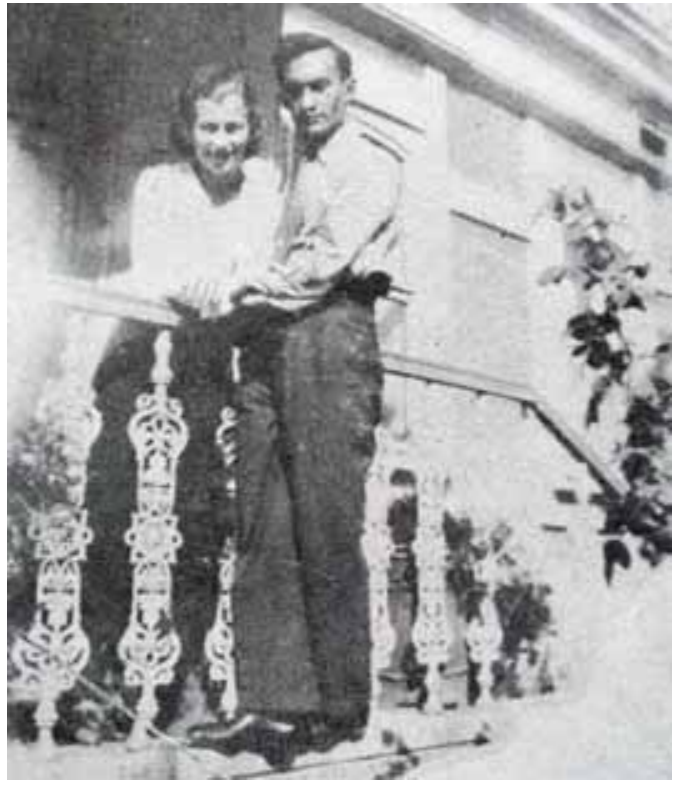

Figure 3. Branka and Pavle Savić in Požarevac, May 1943 [2]

In 1935 he was awarded a scholarship for scientific education in France, by the French government, and at the end of 1935 he came to Paris with his wife Branka, whom he married in 1934. Branka was a student of mathematics, but she had to leave her studies because of their trip to Paris $[1,2]$.

At that time, the French government wanted to increase a number of scholarship beneficiaries to oppose pro-Hitler course of the foreign policy of Stojadinović's government in
Yugoslavia. With the recommendation from Professor Jovanović and paper they published in the "Comptes rendus" of the French Academy in his student's days, Savić applied to the Radium Institute. He was admitted and assigned to work in a library [2].

In 1935, just in time when Savić came to France and started his work at the Radium Institute, Irène Joliot-Curie and her husband Frédéric Joliot received the Nobel Prize in chemistry for artificially synthesizing a radioactive isotope of phosphorus by bombarding aluminum with alpha particles [3].

In 1936 Irène Joliot-Curie invited Savić to work with her on the on the phenomena resulting from bombardment of the uranium with neutrons. Thanks to this invitation and good cooperation which was developed between them, Savić received a scholarship from the Radium Institute, paid from the Carnegie - Curie fund, and his initial six - month scholarship turned into three years stay and work in Paris.

He described this period as very exhausting, three hungry years as he said, during which he and his wife, and very soon his daughter, had to live on the scholarship which was no more than 750 French francs.

Enrico Fermi was the first to start this kind of research with his associates in 1934. They were trying to produce elements heavier than uranium by bombarding uranium with neutrons. As a result, they created new elements, Plutonium with atomic number 94, and Neptunium with atomic number 93. After receiving the Nobel Prize in Physics, in 1938, for demonstrations of the existence of new radioactive elements produced by neutron irradiation, and for his related discovery of nuclear reactions brought about by slow neutrons, Fermi could not continue his work in Mussolini's Italy because of his Jewish ancestry and moved to the USA. In Germany, work on transuranium elements was continued by Otto Hahn, Fritz Strassman and Lise Meitner. Being a Jew as Fermi, Meitner was forced to immigrate to Sweden. The first paper published from the work of the German scientists, describing the series of the elements created from bombarding uranium by neutrons and considered for transuranium elements was a starting point for cooperation of Irène Joliot and Pavle Savić in this field in 1936. Soon, new papers describing new products resulting from Hahn and Strassman's work were published, and all the elements created were defined as transuranium elements. Today, we know that these are all fission products of the uranium nucleus, but at that time it was only clear that there were too many new elements with respect to the available numbers in the Mendeleev system [2].

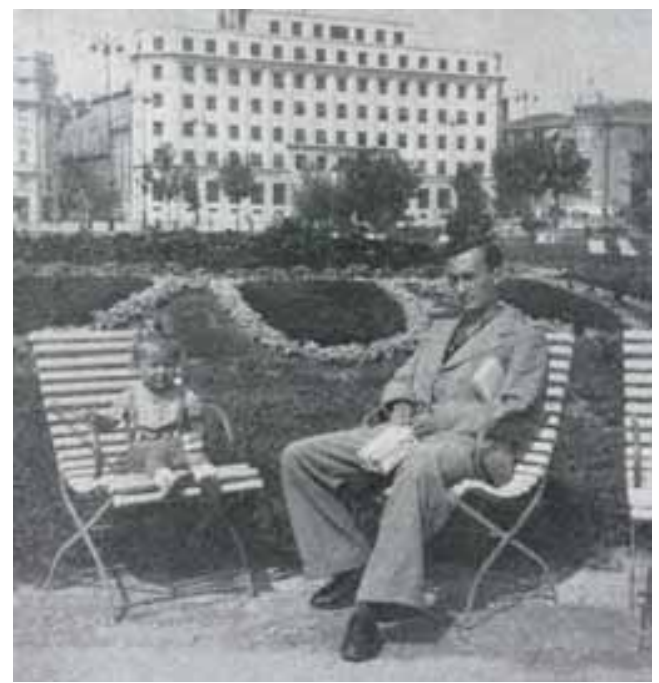

Figure 4. Pavle Savić with daughter Ana in Marseille, 1938 [2] 
With their patient and dedicated work, Savić and Joliot identified an element with half-life of 3.5 hours, formed during the bombardment of uranium with neutrons. This discovery changed direction of research of this phenomena and led to discovery of nuclear fission. Irène Joliot and Pavle Savić published their first paper on this subject in the "Journal of Physique" (3), in September of 1937, and this was in fact a discovery of the first fission product and in this way the discovery of the new process in the atomic nucleus, which shall be two years later, named by Hahn and Strassman as splitting of the uranium nucleus, today generally called fission.

"I was aware, from the journals and magazines, that at the beginning of 1939 Irène Joliot and I were nominated for the Nobel Prize. Beginning of the Second World War postponed this issue, and later, in 1944, the Nobel Prize was awarded to Hahn only, and according to the first formulation it was awarded for work in radiochemistry. Since there was no reaction from neither Irène nor Frédéric Joliot, this formulation was changed in terms of awarding the Nobel Prize for the discovery of fission." - Pavle Savić [2].

In 1939 Savić conducted experiments, trying to verify that besides barium, krypton was also created during bombardment of the uranium by neutrons. He proved that gaseous radioactive product with half-life time of 20 minutes was created.

In the same year, he took part in the experiments measuring the efficient neutron cross section for uranium fission, obtaining the results that were later used for calculation of the chain reactions in the nuclear reactors and nuclear weapons [3].

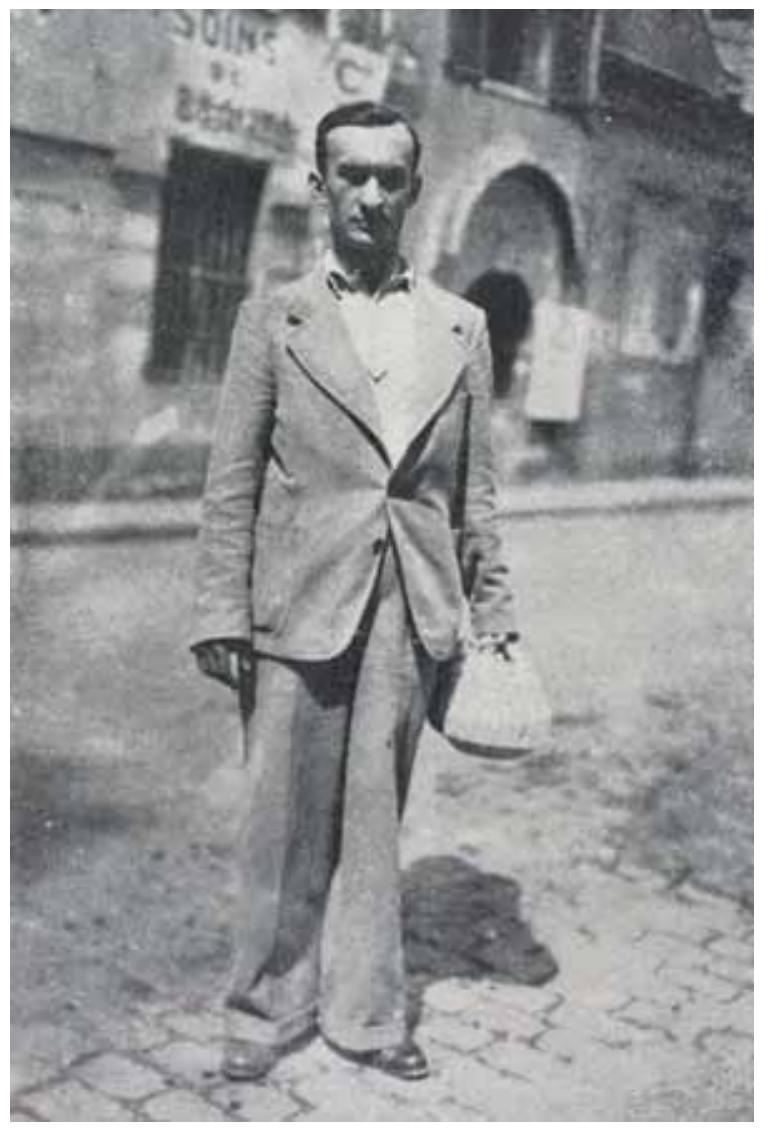

Figure 5. Pavle Savić in Paris, 1937 [2]

In 1937, at the time when a bloody civil war against profascist coalition broke in Spain, several hundreds of
Yugoslavian students in Paris were engaged in the anti-fascist association. Since he was an immediate and sole associate of Irène Joliot who was state undersecretary of the French government, Pavle Savić was the right candidate for the president of the Association of Yugoslav Students. At that time, he met Boris Kidrič, who arrived to Paris from Prague where he was studying chemistry, and he joined the cell Kidrič organized. The purpose of this cell was studying of Marxism - Leninism. As the profascist course of the Yugoslavian government grew stronger, the Association of Yugoslav Students came under the strong pressure between the official representatives of the Yugoslavian Government in France and Paris Police, which was the most reactionary part of the French administration. Despite these circumstances, the association survived and provided significant help in accepting the Yugoslav volunteers of the Spanish Republican Army. In later days, after the collapse of the Spanish Republican Army, the association provided shelter to disabled and illegals of all nations. For more than two years, Pavle Savić was a president of this association. His engagement in the association and day and night work in the Radium Institute which was becoming more and more intense were all together very demanding and required a great effort [2].

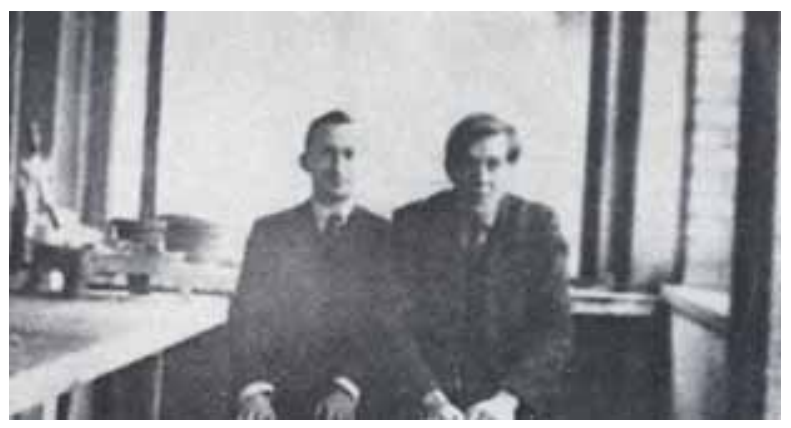

Figure 6. Pavle Savić and Robert Walen, in Paris 1938, in the laboratory of the Radium Institute [2]

In June of 1939, just when the difficulties related to the uranium testing on the Radium Institute were at their peak, Savić was admitted to the Communist Party. This has brought even more responsibilities and intensified work in the Association of Yugoslav Students in Paris and increased his obligations to the participants of the Spanish Civil War. During his short illegal visit to Paris, Josip Broz Tito and Savić met for the first time, and Tito spent a short time in his apartment.

The situation in France was clearly indicating upcoming turbulent days and before the war was declared by France and England to Hitler's Germany, works in the Radium institute were terminated. After the war was announced, Savić applied to the French army, but he was expelled from Paris on December $25^{\text {th }}$, with the deadline to exit the French border within 12 hours [2].

He returned to Belgrade from Paris, where he started to work as the full professor of the Physical Chemistry at the Pharmaceutical Department of the Faculty of Medicine. He remained on this position until the beginning of the Second World War in Yugoslavia in 1941 and continued illegal activities at the university as the member of the Communist Party of Yugoslavia.

In the laboratory of the Institute for Chemistry at the Faculty of Medicine he constructed illegal radio station which was destroyed in bombing of Belgrade in April 1941. At the beginning of the occupation, he continued his illegal activities in Belgrade. He was in contact with a politburo member Sreten Žujović. For Žujović, he was preparing recipes for 
dynamite and supplying chemicals. At the same time, his parent's home, where he lived with his family, was a safe place for meetings and provided shelter to illegals, amongst them to Josip Broz Tito.

In July of 1941, Pavle and Branka Savić, following the party assignment, headed towards free territory in western Serbia. For some time they were hiding in the villages near Čačak, and in the end of 1941, they arrived to Užice, which was the center of the free territory. From Užice, radio connection with Moscow was established, and Pavle Savić started his duty as a cipher officer in the Supreme Headquarters of the National Liberation Army and Partisan Detachments of Yugoslavia. In the large explosion at the ammunition factory in Užice, which occurred on November $22^{\text {nd }} 1941$, Savić suffered burns to face and hands, but unlike the radiotelegraphist and other 200 partisans, he survived. He remained with the Supreme Headquarters until the retreat to eastern Bosnia in 1941. During 1942 he was following the Supreme Headquarters through Bosnia, performing the duty of the cipher officer with his wife Branka. At the end of 1942, when he was appointed duties of the councillor and commissioner of AVNOJ (Anti Fascist Council for the National Liberation of Yugoslavia), Branka assumed the duty of the cipher officer [1].

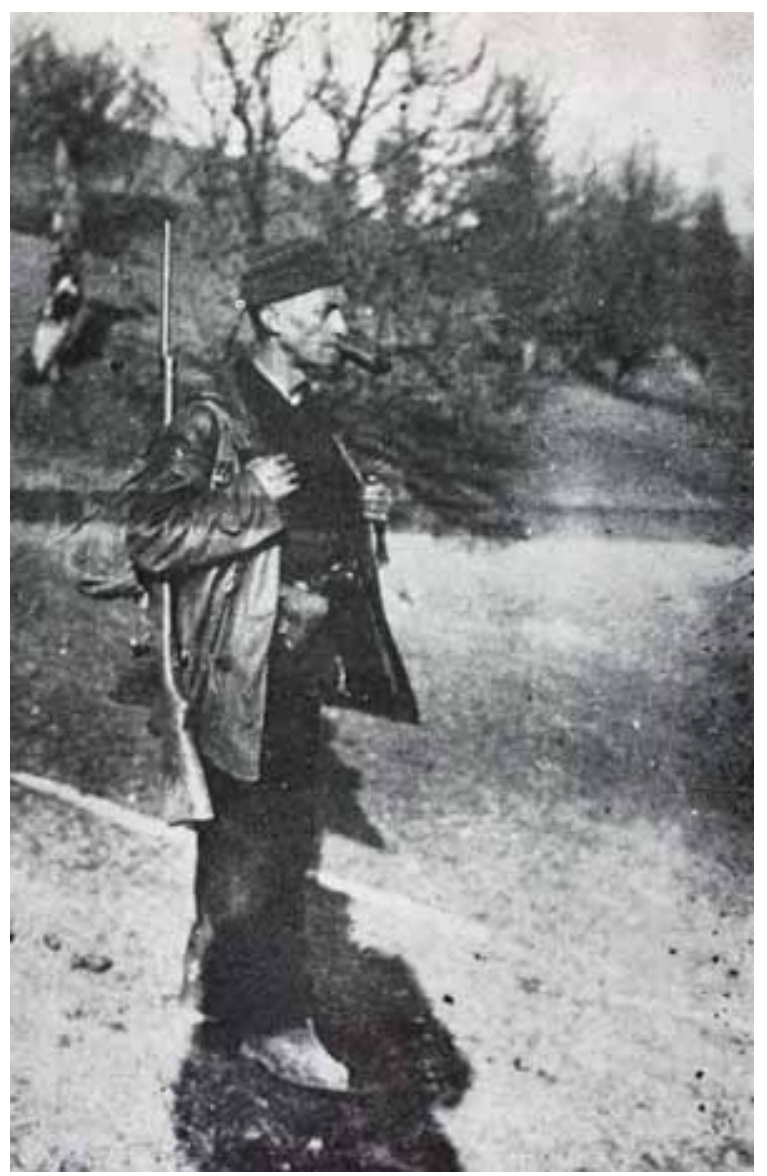

Figure 7. On the watch in Glamoč, 1943 [2]

In 1942, as a member of the AVNOJ Executive Board, he became a President of the Education Department. The Department immediately started to work. Educational issues were studied, classes in the primary schools in Bihać and liberated territory were initiated, instructions for works in schools were written, the National University was opened and its statute was adopted. The main focus of the department was the elimination of the illiteracy on the liberated territory, so the main task, apart from opening the schools and the National University, was establishment of courses for illiterates. In addition to learning letters and arithmetic, the courses envisaged lessons from national history, social sciences and basic elements of economy.

During the fourth German offensive, the Executive Committee withdrew to Bosanski Petrovac, Glamoč and Livno. Pavle Savić stayed with the Supreme Headquarters only until July 1943, when he fell into disfavor with the highest leadership and was removed from all his duties and from the Supreme Headquarters. First he was reassigned to the $7^{\text {th }}$ Krajina Brigade as an ordinary soldier and from there to the $3^{\text {rd }}$ and then to the $1^{\text {st }}$ Division. In the meantime, as a councillor, he participated in the second session of AVNOJ, held on November $29^{\text {th }}-30^{\text {th }}, 1943$ [1].

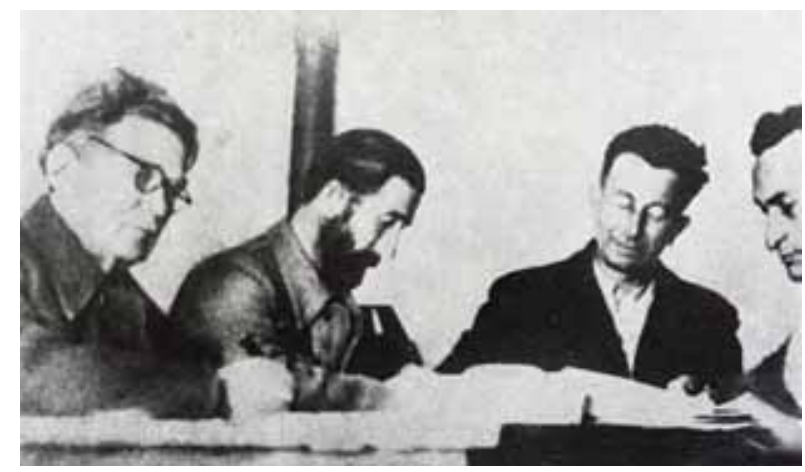

Figure 8. Dr. Ivan Ribar, Vlada Zečević, dr.Sima Milošević and Pavle Savić in villageVidoši near Livno, in February 1943, signing bonds of the loan for the National Liberation Army and Partisan Detachments of Yugoslavia, as the members of the AVNOJ executive committee (Savić is sitting first on the right) [2]

In April of 1944 he was promoted from an ordinary soldier to the rank of Major, and as a member of the military mission of the Supreme Head quarters of the National Liberation Army of Yugoslavia, he left from Drvar to Bari, and then through Malta, Morocco, Cairo, Tehran and Baku he arrived to Moscow.

The goal of the mission was to organize the Soviet help for the National Liberation Army of Yugoslavia, obtain credit and distribution of the foreign aid and investigate possibilities of the international recognition of the new government [1,2].

Upon his arrival to Moscow in April 1944, Pavle Savic tried to work on affairs of the military mission, but he was not very willing to commit to this work. During the first part of his stay he was working on finding children of the Yugoslavian communists who were evacuated from Moscow in late 1941. He was very soon elected for one of the vice presidents of the All-Slovenian Committee.

In the summer of 1944 the First All - Slovenian congress was to be held in the USA. Pavle Savić was appointed to be one of the delegates. In order to accompany other members of the delegation on this trip, his Soviet exit visa and the USA entry visa had to be approved. In the meantime, the Supreme Headquarters promoted Savić in to the Lieutenant Colonel rank and decorated him with the Order of the Partisan Star II rank. He was also sent two Orders of the People's Liberation he was supposed to hand over to Luj Adamić and Baloković up on his arrival to America, in recognition of their struggle to break the truth about Yugoslavia during the war amongst our emigrants and in the American public. While he was waiting for the approval of the visas, the All -Slovenian committee published the book "Blgarskoe carstvo", by Bulgarian historian Derezavin, containing great Bulgarian ideas with respect to both Macedonian and Serbian nations, without 
notifying Savić, who was the committee vice president. His very tempestuous reaction and disapproval of this book most likely were the reason why he did not go on this trip [2].

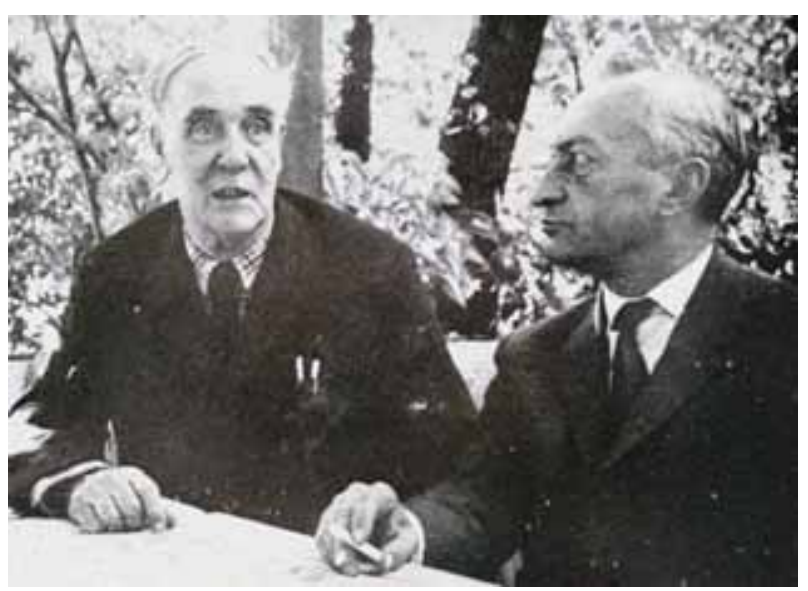

Figure 9. Pyotr Leonidovich Kapitsa and Pavle Savić in September 1966 [2]

Approximately one month upon his arrival to Moscow, Pavle Savić engaged in scientific work and research. This time, field of his work was diametrically opposite to the research he was previously involved in. The Institute for Physical Problems, concerned with low temperature physics phenomena, was one of the first institutes to return to Moscow from evacuation. Opposite to the highest level of energy changes in the process of the nuclear fission, the lowest temperature phenomena were related to the lowest energy changes.

The head of this institute was Pyotr Leonidovich Kapitsa. Savić spent two years working in his institute. Kapitsa was a great physicist involved in a very wide range of research and a pioneer of the physics of the strong magnetic fields. He developed a method for production of large quantity of liquid oxygen. This invention significantly improved production of high quality steel in the Soviet Union during the Second World War.

In the institute Savić was working with Aleksandr Josifovich Shalynikov, deputy of the Pyotr Kapitsa. He became interested in liquid helium, unique element whose superfluidity was discovered just before the Second World War. He was conducting experiments related to the phenomena resulting from changes of the properties of thin surface film of the liquid helium. In a very short period he mastered the technique of working with liquid helium and conducted tens of various experiments.

At the height of the most intensive research, Savić was requested to return to Yugoslavia. In Belgrade, after many years of war, he was reunited with his family members. A year and a half later he returned to the Institute. This time he stayed in Moscow for an approximately one year and continued to research properties of the liquid helium. Shalynikov was helping him in his experiments, and they observed that at the transient from liquid to super liquid helium, particles floating in the substance lose their stability and fall. In 1958 Pavle Savić was elected a foreign member of the Academy of Sciences of the USSR [2].

Immediately after the liberation of Belgrade, Savić joined in the renewal of the work at the Belgrade University. In 1944 he took part in the Solemn Academy of students and professors, dedicated to the national liberation struggle and future role of the university. In November 1944 he participated in the Anti-fascist Assembly for the National Liberation of Serbia and was elected a Member of Presidency and Commissioner for renewal of Serbia and was elected a member of the Central Committee of the Communist Party of Serbia.

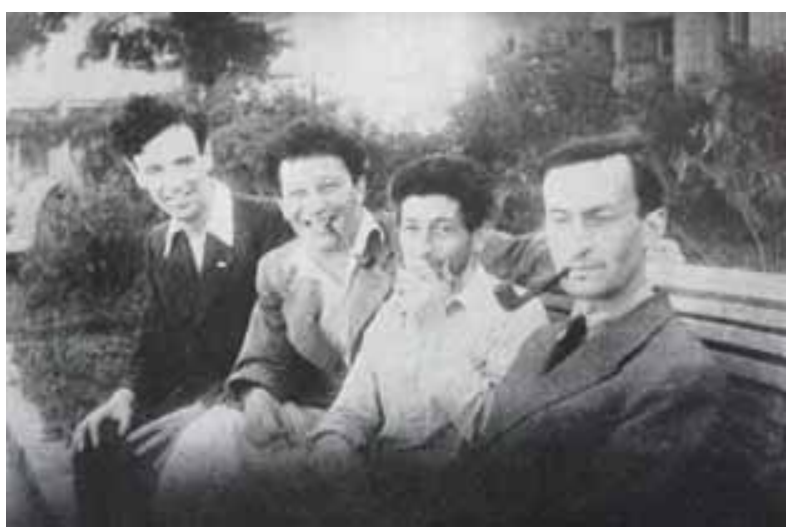

Figure 10. Lev Davidovich Landau, Abraham Isahakovich Alikhanov, Aleksandr Josifovich Shalynikov and Pavle Savić in Moscow, June 1944 (Savić is sitting first on the right)."In the institute I was working with Aleksandr Josifovich Shaalynikov. In our research we have discovered a phenomenon in the field of low temperature physics - the fog phenomenon and I have established a new method for obtaining the low temperatures." Pavle Savić [2]

In August 1945, at the third session of AVNOJ he became a member of the Legislative Committee and a member of the Constituent Assembly. In September 1945 he was elected a full time professor at the Faculty of Philosophy in Belgrade, and later the vicepresident of the Belgrade University, corresponding member of the Serbian Academy of Sciences and Arts in March 1946 and a full member in March 1948.

During his second stay in Moscow, when he continued work on the liquid helium, his main attention was dedicated to providing resources, both human and material, for establishing of the Institute of Physics in Serbia. He was supported and encouraged in this endeavor by the government and party authorities. He succeeded in providing help of the Russian scientists and sent a detailed design for founding and construction of the Institute of Physics in Serbia to Josip Broz.

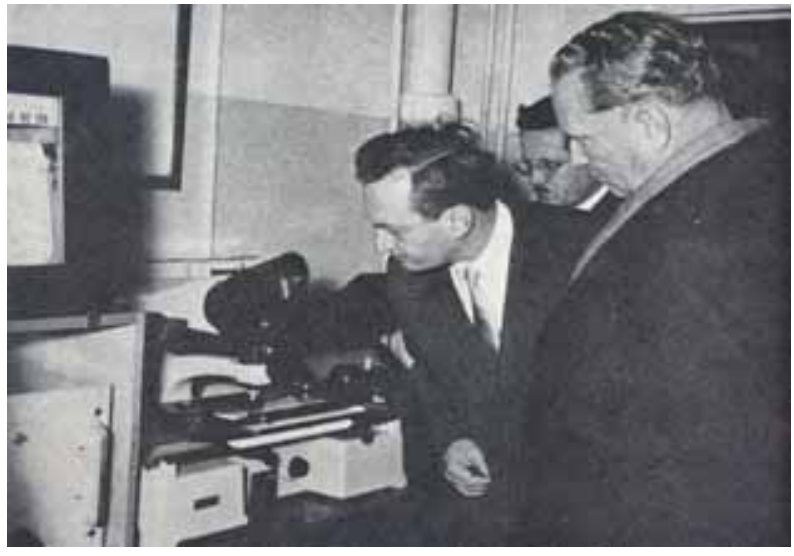

Figure 11. Pavle Savić with Josip Broz Tito and Edvard Kardelj during the visit to the Institute Vinča

In September 1946, when he came back from the Soviet Union, Pavle Savić started to work on the construction of the Institute of Physics in Vinča [1].

He devoted all his strength and will to these works. With him, several of his colleagues sharing his enthusiasm were included, but he was finishing all of the most important tasks himself. He designed and monitored the construction of the most of the initial laboratories (for physics, chemistry and 
biology) living on the farm close to building site. Based on his effort and expertise soon after the construction work was done, the institute was provided with the instruments for scientific research, on an account of war reparations [4].

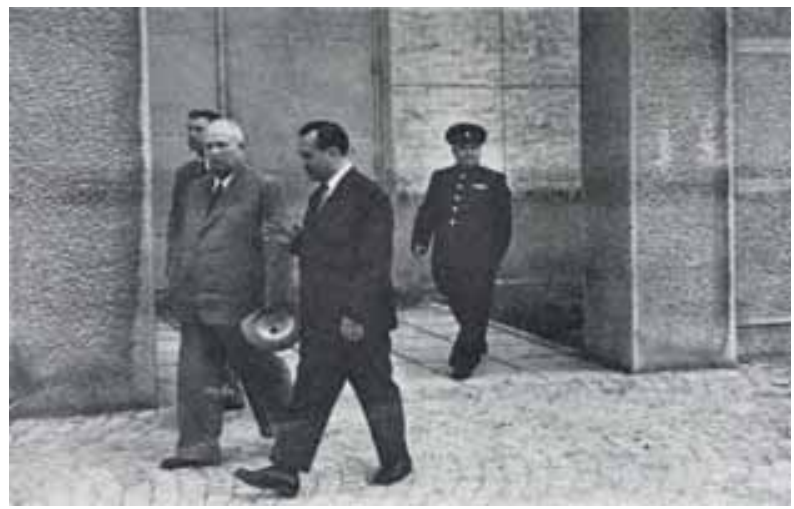

Figure 12. Nikita Sergejevich Hrushcov during the visit to Institut Vinča in 1955, with Pavle Savić

A French scientist with left political orientation, Robert Walen, spent six years in Vinča, helping Pavle Savic in his efforts to build the Institute. Savić was the principal of the Institute Vinča from 1960 - 1966, but due to the political disagreements he left the institute and returned to the University [5].

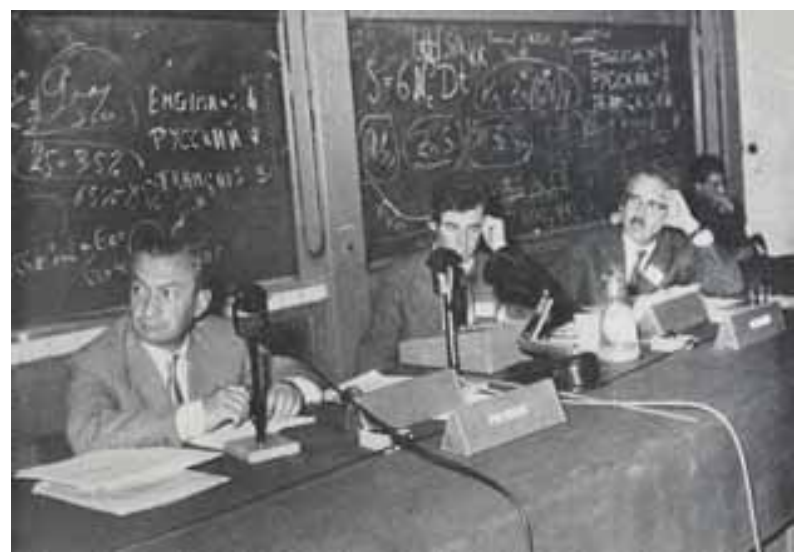

Figure 13. Pavle Savić participates in the International Conference on the Application of Radioisotopes in Scientific Research Work held in Paris in September 1957 [2]

In 1960, in the Serbian Academy of Sciences and Arts, Savić presented his hypothesis about the origin of the rotation of celestial bodies. Based on this hypothesis he continued to study the properties of the materials exposed to the high pressure, with the academician Radivoje Kašanin. In 1969, based on this theory, Pavle Savić presented a statement on the theoretical predictions on the composition of the Moon. The results obtained from the epochal launching of the Soviet Cosmic Rocket "Luna II" confirmed his predictions that the moon has no magnetic fields and that it has only two layers, this being the consequence of the fact that inside the Moon no high pressures are formed.

In an interview published in the Evening News in 1966 , when asked to point up important moments and results of his scientific work, he said that with no doubt, his work in Paris was amongst the most important, but that in his opinion, one of the most mature concepts of his work was the analysis of the behavior of the materials under the extremely high pressures, which he performed with his colleague Radivoj Kašanin [2].
His research of the Behaviour of materials under high pressure was translated in to English, and in USSR it was published as a book. During this period he wrote a popular book "From the atom to the celestial bodies", book "Science and society" and with his daughter Ana he translated "Atomic energy" by Samuel Glasstone [6].

Until the very end of the Socialist Yugoslavia, which he outlived, with his great scientific and party authority, Pavle Savić had a prominent role in the sociopolitical, educational and scientific life of the country. His work was internationally acknowledged and rewarded, he was a member of all Yugoslav academies of science, president of SANU (Serbian Academy of Sciences and Arts) from 1971 to 1981, but also a member of the Academy of Science of USSR(1958), New York Academy of Science (1960), Hungarian Academy of Science (1970), Academy of Athens (1975), etc [1].

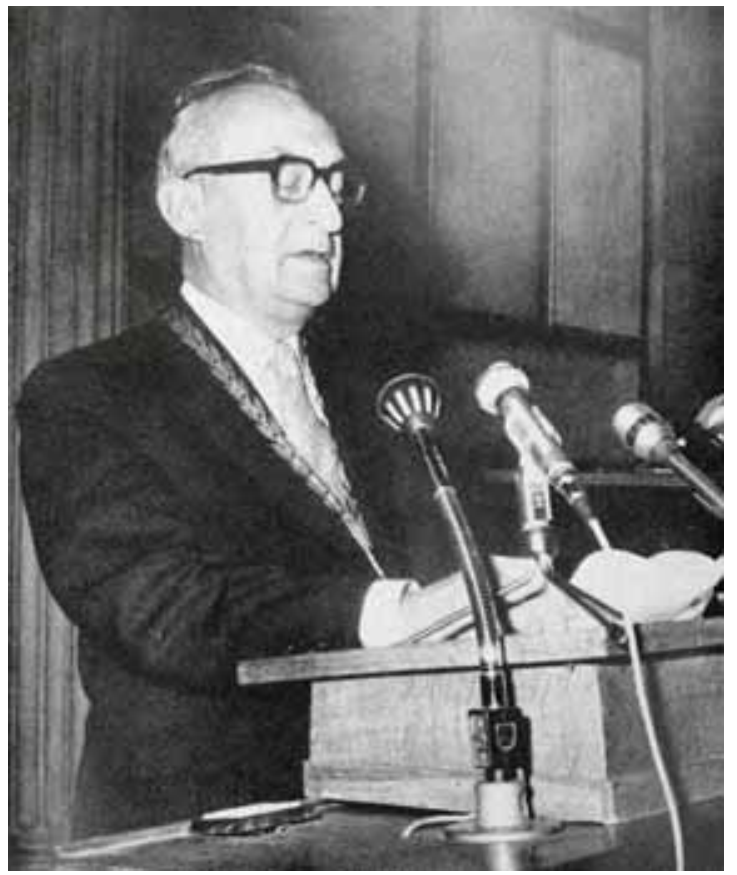

Figure 14. Pavle Savić gives his admission speech at the Academy of Athens on November $21^{\text {st }}, 1974$ [2]

He was awarded the French Legion of Honor twice, he received the Lomonosov Gold Medal and Rutherford Medal. He also received prominent awards of the former Yugoslavia, $7^{\text {th }}$ July Award in 1950 and AVNOJ award 1966 [3].

In addition to his scientific activities, managing the institute in Vinča, research of the nuclear energy, coordination of the international nuclear cooperation, promotion of peaceful uses of nuclear energy, work att he University and SANU, he was constantly making contribution to creation of the general Yugoslavian scientific and educational politics[1].

Many of the speeches Savić presented reveal his knowledge and respect for humanistic sciences and his philosophy of life that only together humanistic and natural sciences can create an opportunity for overall comprehension of the society and the nature.

Since the war days, when he was the vicepresident of AVNOJ and the President of the Education Department, he was involved in the development and education of the scientific personnel and in the years after the War, as the long time educator, he was creating generations of researches and scientists and fighting for their status in society [2].

He died in Belgrade in 1994 in his home and was buried in the family tomb [3]. 


\section{References}

[1] BONDŽIĆ,D., SAVIĆ,P.: - scientist in the war, Intellectuals and war 1939-1947, Proceedings from the Desnica's Encounters, 2012

[2] SAVIĆ,P.: Science and Society, Arranged by Milica Mužijević, Vladimir Dedijer, Serbian Literary Cooperative 1978

[3] BRACIĆ,M, ,SAVIĆ,P.; www.astronomija.org.rs, (30 July 2017)
[4] https://www.vin.bg.ac.rs/en/about-institute/history-of-the-institute

[5] BUBNJEVIĆ,S., SAVIĆ,P.: VREME 1036, 11.November 2010

[6] CVEKIĆ,M.: The Life and Adventures of Pavle Savić, Politikin zabavnik 3285. 25 September 2015.

Received: 21.10 .2019$. Accepted: 15.11.2019.

\title{
Pionir nuklearnih istraživanja Pavle Savić - naučnik u borbi za istinu
}

\begin{abstract}
Ova izdavačka godina Naučno tehničkog pregleda posvećena je Pavlu Saviću, svetski priznatom naučniku koji dao značajan doprinos otkriću fisije, učestvovao u eksperimentima u oblasti fizike najnižih temperatura i objavio niz radova iz kosmogonije. Bio je blizak saradnik nobelovaca Irene Žolio Kiri i Frederika Žolio i kasnije Pjotra Leonidoviča Kapice. Borba za istinu, koju je smatrao osnovnim moralnim imperativom naučnika, pokretala je njegov naučni rad ali i njegovo društveno angažovanje. Tokom drugog svetskog rata borio se za oslobođenje od nacista u redovima Jugoslovenskih partizana, a po završetku rata preuzeo je značajnu ulogu u stvaranju i razvoju nauke i obrazovanja novonastale države. Borio se za mirnodopsku upotrebu novih naučnih i tehnoloških dostignuća i učestvovao u obrazovanju čitavih generacija naučnika, zalažući se sve vreme za poboljšanje njihovog položaja u društvu.
\end{abstract}

Ključne reči: Pavle Savić, nuklearna fizika, naučnik, istraživački rad, obrazovanje i društveno angažovanje 